\title{
Exchange Rate Behavior of Canada, Japan, the United Kingdom and the United States ${ }^{1}$
}

\author{
M. Ariff* and A. Zarei \\ University Putra Malaysia \\ Sunway University Malaysia
}

Open Economies Review

\begin{abstract}
We revisit a significant research topic on exchange rate behavior by restating the test procedures with an appropriate econometric methodology to re-examine three aspects. (i) Does the inflation (price) factor affect nominal exchange rate? (ii) Do relative interest rates affect a country's exchange rate? (iii) Do the price and interest rate effects hold if controls for non-parity factors are embedded in tests? The quarterly data series for this study are taken over 55 years. The traditional parity condition model with price and interest rate as criterion variables is extended to take into account recently-verified non-parity factors, namely trade, productivity and foreign reserves. The results affirm that both parity factors and also the non-parity factors significantly affect the exchange rates of Canada, Japan, the United Kingdom and the United States. In our view, these findings relating to four free-floating currencies help extend our knowledge on how currency behavior is consistent with parity and non-parity theorems using a relevant methodological approach in this study.
\end{abstract}

Keywords: Exchange rates, Non-parity factors, Panel cointegration, Dynamic OLS, Mean group, Pooled mean group

JEL Classification: F23, F31, G12

We acknowledge with thanks the Editor-in-Chief, George S. Tavlas and two anonymous referees for providing insightful comments and directions for revision of the earlier manuscript submitted to the Journal.

\footnotetext{
* Corresponding author

Faculty of Economics and Management

University Putra Malaysia, 43400 UPM, Serdang, Selangor. Malaysia

Email: ariff13@gmail.com

Phone: (603) 8946-7658
}

Alireza Zarei

Sunway University

Bandar Sunway, Malaysia 


\section{Introduction}

Bahmani-Oskooee et al. (2009) and Fama (1984) dubbed the lack of support for parity theorems as an unsolved "puzzle". Parity theorems uses inflation and interest rate factors, and predict: relative price changes across two trading countries over time is supposed to depreciate the exchange rate, and the relative interest rate changes across two trading countries leads to an appreciation of exchange rate. This research aims to explore why there is a lack of support especially for the price effect prediction of purchasing power parity (PPP) by revisiting the parity theorem research by applying more appropriate econometric tests not available to earlier researchers. The appropriate methods chosen are: panel cointegration; dynamic OLS; mean group; pooled mean group; and dynamic fixed effect, which together also help to estimate the time-toequilibrium in an error correction model. In this paper, we report findings that provide supporting evidence consistent with both the PPP effect and the International Fisher Effect (IFE) on the exchange rates of Japan, Canada, the United Kingdom (UK) and the United States (US), four major economies with free-floating currency management regime. Both relative prices and relative interest rates are shown to have significant impacts on the nominal exchange rates over a test period of 55 years.

Several theories in international economics/finance predict how exchange rates are determined, although to-date, there is no clear agreement among economists the predictions of these theorems hold in empirical tests. This then calls for a novel approach to re-examine the exchange rate pricing behavior for a selected group of two most popular currencies used by four major countries, using a long-length time series as suggested by some researchers and with up-to-date econometric methodology. This paper explains this new approach, the appropriate modelling and the resulting findings. 
The rest of the paper is organized into five sections. Although there is vast literature on this topic, the next section is a very brief summary of the theories and the main empirical findings on exchange rate behavior. The data sources, hypotheses and tests are explained in the third section. The findings are reported in the fourth section and the paper ends with a summary in section five.

\section{Review of Exchange Rate Literature}

\subsection{Theories}

The focus of this section is on two major theories on exchange rate determination: Cassel (1918) for PPP and Fisher (1930) for IFE. These theories have been tested in many studies as well as applied in practical policy decisions in a variety of contexts. The theories suggest three research questions: (i) Does PPP factor affect exchange rate; (ii) Does IFE affect exchange rate; and (iii) Do PPP and IFE hold if controls for already-known non-parity factors are embedded in tests? To the traditional factors of parity conditions, we added recently theorized and tested non-parity factors in order to ensure that these factors may serve as controls in the parity models tested.

Existing studies suggest large variation in several currency exchange rates under the free-floating system, which started in earnest in 1973 after a 3-year experiment with Smithsonian Agreement, which was an experiment when the fixed exchange rate term of the Bretton Woods Agreement was cancelled in 1971. Since then, researchers have begun to re-examine the exchange rate behavior especially after the Global Financial Crisis (GFC) in 2008-9, when currency trading volume jumped almost 60 per cent. There is a growing fresh interest on both theoretical and empirical studies to explain exchange rate variation.

Under the monetarist approach of exchange rate determination, the PPP and IFE should fully explain how currency exchange rates are determined. In fact the policy makers place lot of faith in 
this while there is no unanimity of findings to support theories. Scant evidence is available that the PPP holds in the short-run although, using more recently-available approaches, one study (Manzur \& Ariff, 1995) had provided support for a long-run equilibrium only: see also Hall et al. (2013). The novel approach used, among others, is the Divisia Index method, which enables the multicountry currency effect by value-weighting the variables in the model by the relative size of the national incomes of the group of countries in the sample. There is sufficient literature supporting IFE effect on the exchange rate although there is contrary evidence as well: Edison \& Melick (1999). Hence, the literature relevant to this study is from studies on inflation and interest rate differences as well as known non-parity factors. Our review of literature is limited to these factors. Recent researchers have added few non-parity factors (Ho \& Ariff, 2012) to the two parity factors from monetary theories.

\subsubsection{Purchasing Power Parity}

PPP is often said to have originated in Spanish literature on inflation during the periods of gold importation from the New World. ${ }^{2}$ The PPP suggests that the exchange rate changes periodically by the amount of relative price differences in traded goods/services (Cassel, 1918). It asserts that inflation, usually measured as price differentials across any two trading countries, should be offset by exchange rate changes: (Canarella et al., 2014). Hence, any two identical goods produced in any two countries are said to have the same base price, as stated by the law of one price for the same basket of goods traded across two economies with different currencies.

\footnotetext{
${ }^{2}$ See Camarero, M., \& Tamarit, C. (1996). Cointegration and the PPP and the UIP hypotheses: An application to the Spanish integration in the EC. Open Economies Review, 7(1), 61-76.
} 
Scholars in international finance and macroeconomics have found PPP's potential for a wide range of applications especially in the post-Bretton Woods era. It also provides a basis for international comparison of income and expenditure under an equilibrium condition, given an efficient arbitrage in goods traded. Most importantly, it is a theory for short-run as well as long-run exchange rate determination (Ho \& Ariff, 2012), whereby the authorities would set or steer a nominal exchange rate that satisfies international competition.

The relative version of PPP states that a country's currency will be adjusted based on the ratio of the inflation with a trading partner's inflation. Subject to periodic fluctuations of real exchange rates, there is a possibility for the relative PPP to hold in the long-run but not the short-run. This study uses the relative PPP as in:

$\ln E_{j t}=a_{j}+b_{j} \ln \left(\frac{P_{t}^{d}}{P_{t}^{f}}\right)_{j t}+\mu_{j t}$

where, $E$ is the Exchange rate of country $j$ over time period $t, P^{d}$ is the Domestic prices, $P^{f}$ is Foreign prices and $\mu_{j t}$ are the residuals in the equation.

\subsubsection{International Fisher Effect, IFE}

A linkage between interest rate and inflation is postulated in a so called theory of interest (Fisher (1930) which predicts that the nominal interest rate is equal to the summation of real interest and expected inflation rates dubbed the Domestic Fisher Effect. There is a further prediction that such a behavior would also lead to the interest rate differences across any two nations would be met by a corresponding change in the nominal exchange rate. The relationship between interest rates and inflation is one to one, assuming a world of perfect capital mobility with no transaction costs. Furthermore, the real interest rate is assumed to be unrelated to the expected inflation with its value 
determined solely by real economic factors such as capital productivity and investor time preference. This hypothesis plays a crucial role, given the fact that, subject to the correlation between real interest rate and inflation, the nominal interest rate will not be fully adjusted after a change in expected inflation. A large number of studies going back to the 1980s have been conducted on the IFE, yet there are mixed findings on IFE theorem.

Any change in a country's interest rate will create disequilibrium in its currency requiring longterm adjustments of the other country's exchange rate to restore the new equilibrium. In other words, the ratio of changes in exchange rates is determined by the ratio of domestic to foreign relative interest rate as shown in:

$\frac{E_{t+1}}{E_{t}}=\left(\frac{1+i_{t}^{d}}{1+i_{t}^{f}}\right)$

where $i^{d}$ is the domestic interest rate, $i^{f}$ represents foreign interest rate, and $E$ is defined as in Eq. (1).

Accordingly, the IFE states that the interest rate differences across countries are unbiased predictors of any future changes in the spot nominal exchange rates. Tests on this theorem suggest that the interest rate differences are correlated significantly with exchange rate changes, although most tests show that, due to under-specification of the relationship in a test model, the R-squared values tend to be low. Hence, there is also a need to re-examine if such test results are due to methodology used in prior research.

\subsection{Non-Parity Factors}

Given the lack of explanatory power of the monetary theorems with two parity conditions, there have been several important studies exploring if one or more non-parity factors are also relevant 
for exchange rate movements. Several other such factors are tested in another study, Ho \& Ariff op cit., identifying three key non-parity factors as being relevant to theory-building on exchange rates. Hence, this study incorporates these non-parity factors as control variables in the tests of parity theorems. Thus, we believe that the introduction of a fully-specified model with parity and non-parity factors would lead to robust results on exchange rate behavior compared to the existing studies limited to the parity factors only. Hence, the resulting findings from this research may provide fresh insights on the very old issue of parity factors.

\subsection{Empirical Evidence}

Because the nominal prices are unstable or may be sticky or the nominal exchange rates could be subject to wide fluctuations due to volatilities in flows of capital, goods and services, the short-run equilibrium is unlikely to hold. Several concerns have been expressed about this position of the literature. For example, if interest rates - which are also subjected to similar effects - do hold in the short-run, why is there lack of evidence for similar behavior in the case of inflation? The mixed evidence on PPP equilibrium can be attributed to deficiency in exchange rate determination models or to the use of particular test models.

The basic empirical studies on PPP before the 1980s are mostly concerned about the tests of absolute PPP with results rejecting the PPP hypothesis. One later paper, perhaps the most influential study of this type (Frenkel, 1976), obtained estimates of respective coefficients that did not suggest a rejection of the null hypothesis, even though the sampled countries in that study are among high- inflation economies.

A large number of studies in the late 1970s also failed to validate a significant PPP relationship mainly due to the non-stationarity of the residuals, as we have come to discover since the 1980s. 
In particular, while these studies failed to confirm the unit root to verify stationarity of data series, the relationship between the respective variables was mis-measured resulting in spurious regression parameters. Accordingly, in the early1980s, researchers began to test for stationarity using newly developed unit-root tests, namely Dickey-Fuller's ADF test (Dickey \& Fuller, 1981). The ADF test, despite its revolutionary nature, still failed to support the presence of significant PPP effect in nearly all studies of unit-root tests using cross country data from the free floating period, except a few papers evidencing a long-run PPP behavior, given that the real exchange rate deviations from its mean value are only temporary in nature. Such failure to support the theory is attributed to the limited power of the tests, especially if small samples are used or even if simulation is used (Levin \& Lin, 1992).

Towards the late 1980s, researchers attempted to overcome the problem of unit root's low power by taking advantage of long horizon spans of data. By using an error-correction model (Edison, 1987), researchers analyzed the US Dollar and UK Sterling Pound data over a long period and found slightly higher degree of support for the PPP. Consistent with this, a large number of other studies followed in the early 1990s attempting to test for PPP reliability over longer time horizons while using a number of newer methods. The results of these studies favored the PPP predictions: these also supported the real exchange rate mean-reverting behavior (Rogoff, 1996). Mollick (1999) used data for Brazil over 1885 to 1990. The results, however, were mixed: the unit root hypothesis was not rejected by the formal unit root tests. Autoregressive processes used in the model yielded robust and satisfactory estimates of real exchange rate compared with regression methods.

Lothian \& Taylor (1996) used the annual real exchange rate data over two centuries for FrancPound Sterling and Dollar-Pound Sterling. The results also rejected the null hypothesis of unit root 
using both ADF and Phillips-Perron (PP) test (Phillips \& Perron, 1988). Using a relatively similar but smaller sample, Shively (2001) found evidence of a consistent PPP relationship. Likewise, Holmes (2008) applied unit-root test and reported evidence of a long run relationship between inflation and exchange rate in Latin American countries.

Dimitriou \& Simos (2013) examine the weak and strong-form PPP using the Dynamic OLS approach, coupled with other particular cointegration methodologies adopted from the existing literature (Gregory \& Hansen, 1996; Hatemi-J, 2008) over 2000-2012. Test results are in favor of weak-form, but not the strong-form PPP. Furthermore, the Johansen cointegration approach is used in (Canarella et al., 2014) to validate the existence of long-run relationship between price, the exchange rate and the interest rate. The study fails to support a cointegration between interest rate and PPP.

The relationship between inflation and real exchange rate is the topic of several studies using postBretton Woods data. One primary and yet well-known model of exchange rate is the sticky price model of Dornbusch (1976). It suggests that, under a flexible exchange rate framework, prices of goods (inflation) in a country are subject to slower (stickier) adjustments than those that produce capital assets. This would initiate arbitrage opportunities in the short-run, as suggested by the IFE (see Manzur \& Ariff, 1995) thus helping to identify time periods to equilibrium arising from price stickiness.

Apart from these models, there is evidence from several important studies on the correlation of real interest and exchange rates. Mishkin (1984) considers the equality of real interest rates across a sample of major economies. Likewise, Mark (1985) tests for the conditions of high capital mobility and equality of short term ex ante real interest rates and the net-of-tax real rates among 
flexible market-linked exchange rates. The results are consistent with those of Mishkin in that the IFE hypothesis of parity conditions was rejected considering its joint relationship with the ex-ante PPP.

Large number of critics made obvious conclusions that there is lack of support for some of the theories concerned with the validity of tests and that the cointegration of real returns are not tested in Mark \& Mishkin's study. Other studies attempted to control for the drawback by introducing tests of cointegration. Notably, the two-step method of Engle-Granger test of co-integration was applied in several preliminary studies in the late 1980s and in the early 1990s in order to examine how the real exchange rates are cointegrated with real interest rates (Meese \& Rogoff, 1988; Edison \& Pauls, 1993; Throop, 1993). The results became somewhat more favorable to support the theory (Johansen \& Juselius, 1992; Edison \& Melick, 1999). There is evidence in several empirical studies that long-run relationship between exchange rate and interest rate changes appears to hold well (Hill, 2004). On the other hand, in the short-run, the IFE has not been shown to hold (Cumby \& Obstfeld, 1981). Fama (1984) suggested that this situation warranted this lack of support for IFE as a "puzzle".

While those theories are generally treated as general equilibrium conditions - known as parity theorems - researchers have recently identified a number of other-than parity factors, as also influencing exchange rates. Given the lack of full explanatory power of parity factors as determinants of exchange rate behavior, these non-parity factors are gaining significant popularity in recent years in exchange rate studies.

The level of international reserves of a country is one significant determinant of exchange rates (Frankel \& Rose, 1996): this comes from the Philip's Curve effect long observed in international 
economics studies. A country's currency is subject to movements as a result of unexpected changes in foreign reserves held by the central authority to service the trade bills arising from international trade and also to defend currency during crisis periods. Hence, there is a direct relationship between the currency value and any sort of unexpected changes in the country's reserve or even the level of foreign currency debt. The relationship between level of international reserve and currency value has been tested by a number of scholars (Martínez, 1999; Marini \& Piersanti, 2003). They show a significant association between the respective variables.

The level of capital flows also plays a crucial role in determining exchange rates. The accessibility to cash from capital markets has become easier because of new rules and regulations and general reduction of capital controls, leading to improved globalization of cash flows. This is partly relevant to exchange rates, given the freedom in global flows of capital. There are several studies that have identified significant relationship between the level of capital flows and exchange rate changes: Kim (2000), Calvo et al. (2003), and Rivera-Batiz \& Rivera-Batiz (2001).

\section{Research Design, Variables and Modeling}

The data series on variables (exchange rate; inflation; interest rate differences; non-parity factors) are from the US, the UK, Japan and Canada. We use data over 1960 from the pre-floating era to 2014. The test model is developed specifying inflation and interest rate difference as parity factors on the right-hand side, and then control variables, which are three non-parity factors. In such a full model, a single regression could do for tests on estimating the effects of parity and non-parity factors. During the test periods, both USD and GBP played significant roles as international currencies. Hence, the tests are done using these currencies, and data from the four respective economies. 


\subsection{Data, Variable Transformation and Testing}

Data employed in this study are Nominal Exchange Rate (NER), Consumer Price Index (CPI), short-term risk-free (Treasury) interest rates, Total Reserve, Total Value of Imports, Current Account Balance, GDP, and Total Value of Exports. The GDP data are used to standardize other variables: the values of Total Trade in each year are standardized by current GDP numbers. The series are monthly and yearly data over 1960-14. Table 1 provides a summary of variables, with their expected signs in tests. The major sources of data are: The International Financial Statistics (IFS) CD-ROM, Thomson Reuters DataStream, the Capital IQ database.

Table 1: Variable specification, definitions and expected signs

\begin{tabular}{lllc}
\hline No. & Variables & Definition & $\begin{array}{c}\text { Expected } \\
\text { Sign }\end{array}$ \\
\hline 1. & LNER & Log of Nominal Exchange Rate over time periods & $\begin{array}{c}\text { Dependent } \\
\text { Variable }\end{array}$ \\
& & & + \\
2. & LCPI & Log of Prices over time periods & - \\
3. & RIFE & $\begin{array}{l}\text { (1+ Short-term Real Domestic Interest Rate) / (1+Short-term Real Foreign } \\
\text { Interest rate) }\end{array}$ & - \\
4. & TTrade/GDP & Total Exports and Imports / GDP & + \\
5. & Prodty & GDP/Total Population & - \\
6. & TRes/M & Total Reserve / Total Import & \\
\hline
\end{tabular}

The Consumer Price Index (CPI) is used as a proxy for purchasing power parity. The CPI measures the prices of a basket of goods available in each country. The IFE is measured according to shortterm risk free interest rates (Treasury bills) for the US, for example, dividing by the interest rate for the UK as a measure for the foreign interest rate for the US. 


\subsection{Hypotheses}

There are three hypotheses that we develop for testing. We pool the data for all four countries to run a panel regression so there is one test at a time to test the hypotheses developed. These are: $\mathrm{H}_{1}$ : The expected changes in relative inflation will not significantly affect the exchange rate of any two or more countries.

This is the null hypothesis, which we expect to reject the null and show that the alternate hypothesis holds. The expected effect on the exchange rate is positive.

$\mathrm{H}_{2}$ : The expected change in relative interest rate will not significantly affect the exchange rate of any two or more countries.

The three non-parity factors are entered as control variables. We expect to observe the same effects on exchange rate as reported in the study cited earlier.

\subsection{Test Model}

The first model for the exchange rate is based on a single equation which includes a number of parity and non-parity factors. The following equation is used to test the basic relationship among the variables.

$\ln \left(\frac{N E R_{t}^{d}}{N E R_{t}^{f}}\right)_{j t}=\alpha_{0}+\gamma_{1}\left(\frac{1+i_{t}^{d}}{1+i_{t}^{f}}\right)_{j t}+\gamma_{2} \ln \left(\frac{C P I_{t}^{d}}{\operatorname{CPI} I_{t}^{f}}\right)_{j t}+\gamma_{3}\left(\frac{T T r a d e}{G D P}\right)_{j t}+\gamma_{4}$ Prodty $+\gamma_{5}\left(\frac{T R e s}{M}\right)_{j t}+\varepsilon_{j t}$

where $\alpha_{0}$ represents the intercept, NER represents the Nominal Exchange Rate, $i^{d}$ denotes the Real Domestic Interest Rate, $i^{f}$ is the Real Foreign Interest Rate, as in the Eq. (2), CPI stands for the Consumer Price Index, as in the Eq. (1), $\frac{\text { TTrade }}{G D P}$ represents the total trade as a proxy of total trade (export and import) over Gross Domestic Product (GDP) over time period t, Prodty is ratio 
of total population over GDP, $\frac{T R e s}{M}$ denotes total reserve over import: j subscript refers to countryspecific data for the four countries ${ }^{3}$.

As a general rule, the validity of co-integrating series is determined by investigating the order of integration of the variables, which by definition, should be similar. One may note that an equilibrium long-run relationship exists between variables (say exchange rate and parity conditions) if the variables are integrated of the same order. Thus, two series are said to be cointegrated if they move in one direction over the long-run: we also apply dynamic OLS (DOLS) of Stock \& Watson (1993) as the robustness test of the ordinary panel cointegration (Pedroni, 1999, 2004). ${ }^{4}$

\section{Findings}

In this section we present the results and discuss why these results are different from the published studies.

\subsection{Description and Diagnostic Statistics}

Table-2 is a summary of descriptive statistics on the variables used in this study. These statistics suggest that the variable means are very close to zero in most cases because of data transformation.

\footnotetext{
${ }^{3}$ The model has included a variable for inflation as the $\ln$ on CPI. Hence, using nominal relative interest rate in the test for IFE would mean that the inflation factor is again included in the second variable. To rectify this, we subtracted the expected inflation from the domestic and the foreign current nominal interest rates so that we test the IFE on the real interest rates.

${ }^{4}$ An anonymous reviewer commented that there could be structural breaks in the time series. The results reported are not likely to suffer from systematic effect of such possible breaks. Several breaks may exist, the combined effect of all of them is likely to be minimal since we used pooled mean group method, which allows for heterogeneity, intercept, slope coefficient and error variances, all of which would limit the effect of structural break in our final results.
} 
Table 2: Descriptive statistics of variables used in test models for yearly data, 1960-2014

\begin{tabular}{llllll}
\hline Variables & Mean & Median & SD $^{\mathbf{a}}$ & Skew $^{\mathbf{b}}$ & Kurt $^{\mathbf{c}}$ \\
\hline Annual Series & & & & & \\
\hline LNER (Dependent variable) & 0.023 & 0.025 & 0.216 & -0.292 & 2.799 \\
LCPI & 1.040 & 1.009 & 0.121 & 0.300 & 4.161 \\
RIFE & -0.375 & -0.355 & 0.458 & -1.567 & 10.51 \\
TTRADE & 0.314 & 0.220 & 0.284 & 1.267 & 3.994 \\
PRODTY & 4.163 & 4.279 & 0.574 & -0.169 & 3.683 \\
TRESM & 0.444 & 0.181 & 0.554 & 1.902 & 6.577 \\
\hline
\end{tabular}

Note: ${ }^{\mathrm{a} S D}$ represents standard deviation. ${ }^{\mathrm{b}} \mathrm{S} k e w$ represents skewness and ${ }^{\mathrm{c}} \mathrm{Kurt}$ denotes kurtosis.

The relative real interest rate is the ratio of two-country interest rates expressed as explained earlier. The non-parity variables are after standardization by GDP (in the case of trade and current account): in the case of reserve, it is divided by total import value. The exchange rate change is about 2.3 per cent per annum with a standard deviation of about 22 per cent. Table 3 is a summary of diagnostic tests using available tests: Breusch (1978) and Godfrey (1978) for serial correlation (SC), the heteroskedasticity test (HE) developed by Breusch \& Pagan (1979), and the stability test (ST) by Ramsey (1969).

Table 3: Diagnostic statistics for serial correlation, heterokedasticity and stability

\begin{tabular}{lcccccccc}
\hline Variables & \multicolumn{3}{c}{ Yearly Data } & \multicolumn{4}{c}{ Monthly Data } \\
& SC $^{\mathbf{a}}$ & HE $^{\mathbf{b}}$ & $\mathbf{S T}^{\mathbf{c}}$ & ${\boldsymbol{A d j} . \boldsymbol{R}^{\mathbf{2}}}$ & $\mathbf{S C}^{\mathbf{a}}$ & HE $^{\mathbf{b}}$ & $\mathbf{S T}^{\mathbf{c}}$ & $\boldsymbol{A d j}_{\mathbf{j}} \boldsymbol{R}^{\mathbf{2}}$ \\
\hline United States & 1.056 & 4.60 & 0.38 & 0.275 & 1.724 & 11.72 & 2.41 & 0.047 \\
United Kingdom & 0.093 & 5.32 & 0.73 & 0.556 & 0.028 & 10.22 & 2.31 & 0.104 \\
Japan & 2.026 & 2.18 & 0.79 & 0.511 & 0.590 & 9.90 & 1.90 & 0.061 \\
Canada & 0.277 & 4.93 & 1.41 & 0.746 & 2.52 & 10.90 & 2.51 & 0.128
\end{tabular}

a: SC indicates Breusch Godfrey LM test for Serial Correlation. b: HE indicates Breusch-Pagan/Cook-Weisberg test for Heteroskedasticity. c: ST indicates Ramsey RESET test for Model Specification. Since none of the test values are significant, we have not placed * in any of them. The R-squared values account for the degree of variation in the dependent variable explained by the models.

In line with the common practice, we have applied time-series analysis. The statistics in the table suggest that there are no issues to be concerned about the econometric assumptions of our models: 
note the footnote to the Table. For example, for SC, the reported values are within bounds of the confidence intervals: similarly, the reported values on HE are smaller than 12.59 (critical value).

\subsection{Panel Unit Root and Cointegration Results}

Table 4 is a summary statistics on the order of integration and the stationarity properties of the variables. To do those, we use two panel unit root tests of Levin \& Lin (1992) (LL) and Im et al. (1995) (IPS).

Table 4: Panel unit root test results on the variables used

\begin{tabular}{|c|c|c|c|c|c|}
\hline \multirow[t]{2}{*}{ Variables } & \multirow[t]{2}{*}{ Deterministic Terms } & \multicolumn{2}{|c|}{ Monthly } & \multicolumn{2}{|c|}{ Annual } \\
\hline & & LL Statistics & IPS Statistics & LL Statistics & IPS Statistics \\
\hline \multicolumn{6}{|l|}{ Levels } \\
\hline NER & Constant, Trend & 1.17 & 0.50 & 0.289 & -0.21 \\
\hline PPP & Constant, Trend & $-3.24 * * *$ & 0.16 & $-1.46^{*}$ & 0.94 \\
\hline RIFE & Constant, Trend & -0.96 & $-4.48 * * *$ & $-5.39 * * *$ & $-6.17 * * *$ \\
\hline TTRADE & Constant, Trend & 0.68 & -1.15 & $-1.71 * *$ & $-1.81 * *$ \\
\hline PRODTY & Constant, Trend & $-2.79 * * *$ & 0.16 & 2.94 & 3.46 \\
\hline TRESM & Constant, Trend & $-8.94 * * *$ & $-3.39 * * *$ & $-4.39 * * *$ & $-1.57 *$ \\
\hline \multicolumn{6}{|c|}{ First Differences } \\
\hline NER & Constant & $-91.1 * * *$ & $-56.91 * * *$ & $-12.2 * * *$ & $-12.5 * * *$ \\
\hline PPP & Constant & $-15.3 * * *$ & $-17.39 * * *$ & $-5.10 * * *$ & $-4.72 * * *$ \\
\hline RIFE & Constant & $-41.9 * * *$ & $-37.20 * * *$ & $-16.4 * * *$ & $-16.5 * * *$ \\
\hline TTRADE & Constant & -0.63 & $-10.76 * * *$ & $-15.1 * * *$ & $-13.6 * * *$ \\
\hline PRODTY & Constant & $-2.48 * * *$ & $-8.96 * * *$ & $-12.4 * * *$ & $-11.5 * * *$ \\
\hline TRESM & Constant & $-12.3 * * *$ & $-14.41 * * *$ & $-3.86 * * *$ & $-6.40 * * *$ \\
\hline
\end{tabular}

The number of lags is determined by the criterion of Schwarz with maximum of five.* Indicates the significance level at $1 \%$.** Indicates the significance level at 5\%.*** Indicates the significance level at $1 \%$.

The panel unit root test have robust properties compared to pure time-series test as it provides consistent estimates of the true values of parameters when both time series and cross-sections tend to infinity. Based on the statistics in the table, we find most of the series are stationary at order 1.

Consistent with panel unit root tests, the panel cointegration tests tend to reveal more powerful and reliable estimates on the two key variables, the prices (PPP) and interest rates (IFE). The test 
for the presence of cointegration between the panel-based variables is conducted after ensuring that the variables are integrated of order one (denoted as I(1)). If the series are cointegrated, then the residuals would be integrated of no order, i.e. I(0). Pedroni (1999, 2004) proposed few cointegration tests for panel data. A distinctive feature of his test is that it allows for considerable heterogeneity.

The result of the Pedroni's cointegration test is reported in Table 5 as follows.

Table 5: Panel cointegration results from for parity and non-parity factors

\begin{tabular}{|c|c|c|c|c|}
\hline \multirow{3}{*}{$\begin{array}{l}\text { Pedroni } \\
\text { Cointegration }\end{array}$} & \multicolumn{4}{|c|}{$N E R=f($ Parity \& Non-parity $)$} \\
\hline & \multicolumn{2}{|c|}{ Monthly $(N=4, T=646)$} & \multicolumn{2}{|c|}{ Annual $(\mathrm{N}=4, T=54)$} \\
\hline & $\begin{array}{l}\text { Model 1a: } \\
\text { Without Trend }\end{array}$ & $\begin{array}{l}\text { Model 1b: } \\
\text { With Trend }\end{array}$ & $\begin{array}{l}\text { Model 2a: } \\
\text { Without } \\
\text { Trend }\end{array}$ & $\begin{array}{l}\text { Model 2b: } \\
\text { With Trend }\end{array}$ \\
\hline Panel v-stat & 4.081 & $3.25 * * *$ & 1.059 & 0.317 \\
\hline Panel rho-stat & $-2.64 *$ & $-2.77 * * *$ & -0.783 & -0.311 \\
\hline Panel pp-stat & $-2.34 * *$ & $-2.56 * * *$ & -1.636 & -1.808 \\
\hline Panel adf-stat & $-2.50 * *$ & $-2.52 * * *$ & $-3.48 *$ & -1.914 \\
\hline Group rho-stat & $-2.26 * *$ & $-3.10 * * *$ & 0.203 & 1.108 \\
\hline Group pp-stat & $-2.46 * * *$ & $-3.15 * * *$ & $-1.38 *$ & -0.467 \\
\hline Group adf-stat & $-2.70 * * *$ & $-4.92 * * *$ & $-2.73 * * *$ & -0.489 \\
\hline
\end{tabular}

*Indicates significance level at 10\%. ** Indicates significance level at 5\%.*** Indicates significance level at $1 \%$. The lag numbers are determined by the criterion of Schwarz with maximum of ten lags. Note that there is full support for the cointegration hypothesis in Model $1 \mathrm{~b}$.

The cointegrating relationship between the parity variables holds for monthly series, given that at least six out of seven test statistics are significant at 10, 5 and 1 per cent significance levels

\subsection{Dynamic OLS Results}

In this section, we present the test results to verify the robustness of the results discussed in the previous sections. 
Table 6 reports the results from applying the Dynamic OLS, DOLS, test, of Kao \& Chiang (2001) as an extension of Stock \& Watson (1993). One basic aim of this test is to correct for endogeneity bias and serial correlation so as to bring about standard normal inferences of the estimators.

Table 5: Results of the Dynamic Ordinary Least Squares estimation for four countries

\begin{tabular}{|c|c|c|c|c|}
\hline \multirow[t]{3}{*}{ Variables } & \multicolumn{4}{|c|}{$N E R=f($ Parity \& Non-parity $)$} \\
\hline & \multicolumn{2}{|c|}{ Monthly $(N=4, T=646)$} & \multicolumn{2}{|c|}{ Annual $(\mathrm{N}=4, \mathrm{~T}=54)$} \\
\hline & $\begin{array}{l}\text { DOLS } \\
(\operatorname{Lag}=2, \text { Lead }=1)\end{array}$ & $\begin{array}{l}\text { DOLS } \\
(\text { Lag =1, Lead = 2) }\end{array}$ & $\begin{array}{l}\text { DOLS } \\
(\operatorname{Lag}=2, \text { Lead }=1)\end{array}$ & $\begin{array}{l}\text { DOLS } \\
(\operatorname{Lag}=1, \text { Lead }=2)\end{array}$ \\
\hline $\begin{array}{l}\text { LCPI } \\
\text { (t-stat) }\end{array}$ & $\begin{array}{l}0.663 \\
(8.29) * * *\end{array}$ & $\begin{array}{l}0.659 \\
(8.24) * * *\end{array}$ & $\begin{array}{l}0.382 \\
(4.36)^{* * * *}\end{array}$ & $\begin{array}{l}0.389 \\
(4.44)^{* * * *}\end{array}$ \\
\hline $\begin{array}{l}\text { RIFE } \\
\text { (t-stat) }\end{array}$ & $\begin{array}{l}-0.017 \\
(-28.43) * * *\end{array}$ & $\begin{array}{l}-0.025 \\
(-40.48) * * *\end{array}$ & $\begin{array}{l}-0.033 \\
(-4.00) * * *\end{array}$ & $\begin{array}{l}-0.038 \\
(-4.53) * * *\end{array}$ \\
\hline TTRADE & 0.480 & 0.048 & 0.021 & 0.017 \\
\hline (t-stat) & $(6.09) * * *$ & $(6.11)^{* * *}$ & $(0.65)$ & $(0.53)$ \\
\hline PRODTY & 0.029 & 0.031 & 0.015 & 0.009 \\
\hline$(\mathrm{t}-\mathrm{stat})$ & $(2.91)^{* * *}$ & $(3.13)^{* * *}$ & $(1.09)$ & $(0.66)$ \\
\hline $\begin{array}{l}\text { TRESM } \\
\text { (t-stat) }\end{array}$ & $\begin{array}{l}-0.160 \\
(-40.69) * * *\end{array}$ & $\begin{array}{l}-0.160 \\
(-40.59) * * *\end{array}$ & $\begin{array}{l}-0.181 \\
(-13.51) * * *\end{array}$ & $\begin{array}{l}-0.188 \\
(-14.02) * * *\end{array}$ \\
\hline
\end{tabular}

* Indicates the significance level at 10\%; ** Indicates the significance level at 5\%; and *** Indicates the significance level at $1 \%$.

The estimators of DOLS augment the static regression parameters with certain lags, leads as well as contemporaneous values of the regressors in first differences. The outcome would be more precise estimation as well as more powerful tests compared with ordinary cointegration tests. Furthermore, the estimator of the DOLS is straightforward for the sake of computation, and relevant test statistics have standard asymptotic distribution (Mark \& Sul, 2003).

The PPP and IFE are always considered as long-run equilibrium theories. Here, we have both variables becoming significant because these tests are more appropriate to yield reliable results. Hence, the significance of both prices and interest rate variables in the Table 6 shows that the theorems hold well with strong correlations with the nominal exchange rate. The coefficient for the PPP factor is tested using also a 2-lag and then refining it to a 1-lag specification. The tests 
with leads and lags are all significant, especially for the parity variables. Note also that the IFE factor also holds well across all four tests. For example the IFE coefficient is -3.8 per cent with a $\mathrm{t}$-value of -4.53 , which is significant at 1 per cent level.

The results also reveal that the non-parity factors (see column 1) are all significant when the model is tested using monthly data set. Controlling the effects of these newly-suggested variables on the exchange rate (Ho \& Ariff, 2012) enables the parity factors to be identified clearly as being significant. The directions of the variables are consistent with the theorems (see expected signs in Table 1).

\subsection{Findings from Mean Group, Pooled-Mean Group and Dynamic Fixed Effect}

We present the final result, which is from an error-correction model test results. Pesaran, Shin \& Smith's $(1995 ; 1999)$ econometric techniques for estimating nonstationary in dynamic panels and their mean-group (MG) and pooled mean group (PMG) are appropriate procedures for obtaining error-correction estimator. The MG estimator helps to obtain an overall average of coefficients after estimating $N$ time-series regressions, while the PMG estimator relies on a combination of pooling and then averaging the coefficients. Assuming there is a long-run relationship between variables being validated, the responsiveness of any sort of deviation from the long-run equilibrium and the speed of such an adjustment are of primary interest to us. Using the Autoregressive Distributed Lag or $\operatorname{ARDL}(1,1,1,1,1,1)$ re-parameterization steps, the following equation is obtained, and tested: 


$$
\begin{aligned}
& \text { lner }_{i t}=\varphi_{0}+\delta_{10 i} \text { lcpi }_{i t}+\delta_{11 i} \text { lcpi }_{i, t-1}+\delta_{20 i} \text { rife }_{i t}+\delta_{21 i} \text { rife }_{i, t-1}+\delta_{30 i} \text { trrade }_{i t}+ \\
& \delta_{31 i} \text { ttrade }_{i, t-1}+\delta_{40 i} \text { prodty }_{i t}+\delta_{41 i} \text { prodty }_{i, t-1}+\delta_{50 i} \text { tresm }_{i t}+\delta_{51 i} \text { tresm }_{i, t-1}+ \\
& \lambda_{i} \operatorname{lner}_{i, t-1} u_{i}+\epsilon_{i t}
\end{aligned}
$$

Accordingly, an error correction model measures the relationship between the short-run dynamics of variables and the deviation from equilibrium as in Eq. (5):

$$
\begin{aligned}
& \Delta \text { lner }_{i t}=\varphi_{0}+\emptyset_{i}\left(\text { lner }_{i, t-1}-\theta_{0 i}-\theta_{1 i} \text { lcpi }_{i t}-\theta_{2 i} \text { rife }_{i t}-\theta_{3 i} \text { ttrade }_{i t}-\right. \\
& \left.\theta_{4 i} \text { prodty }_{i t}-\theta_{5 i} \text { tresm }_{i t}\right)+\delta_{11 i} \Delta \text { lcpi }_{i t}+\delta_{21 i} \Delta r i f e_{i t}+\delta_{31 i} \Delta \text { ttrade }_{i t}+ \\
& \delta_{41 i} \Delta \text { prodty }_{i t}+\delta_{51 i} \Delta \text { tresm }_{i t}+\epsilon_{i t}
\end{aligned}
$$

where, $\varphi_{0}$ is the intercept, $\emptyset_{i}=-\left(1-\lambda_{i}\right), \theta_{0 i}=\frac{u_{i}}{1-\lambda_{i}}, \theta_{i t}=\frac{\delta_{10 i}+\delta_{11 i}}{1-\lambda_{i}}, \theta_{2 i}=\frac{\delta_{20 i}+\delta_{21 i}}{1-\lambda_{i}}, \theta_{3 i}=$ $\frac{\delta_{30 i}+\delta_{31 i}}{1-\lambda_{i}}, \theta_{4 i}=\frac{\delta_{40 i}+\delta_{41 i}}{1-\lambda_{i}}, \theta_{5 i}=\frac{\delta_{50 i}+\delta_{51 i}}{1-\lambda_{i}}$

The error correction coefficient, $\emptyset_{i}$, which is a measure of the speed of adjustment, is expected to be negative and significant in order to verify that a long-run equilibrium exists. Its within-bounds behavior can then be shown in a graph.

While the MG estimates are un-weighted mean of $N$ individual regression coefficients, the PMG estimator allows for heterogeneous short-run dynamics and common long-run parity and nonparity relationship among the respective variables. Similarly, The Dynamic Fixed Effect (DFE) estimation procedure restricts the equality of coefficients of the cointegrating vector, the speed of adjustment coefficient and the short-run coefficients across all panels. The Hausman test statistic is used to examine the differences in the models.

Table 6 is a summary of statistics from the three estimators using annual data series: results from monthly data series are shown in Table 7. 
Table 6: Results from Mean Group, Pooled Mean Group and Dynamic Fixed Effect (Annual Series)

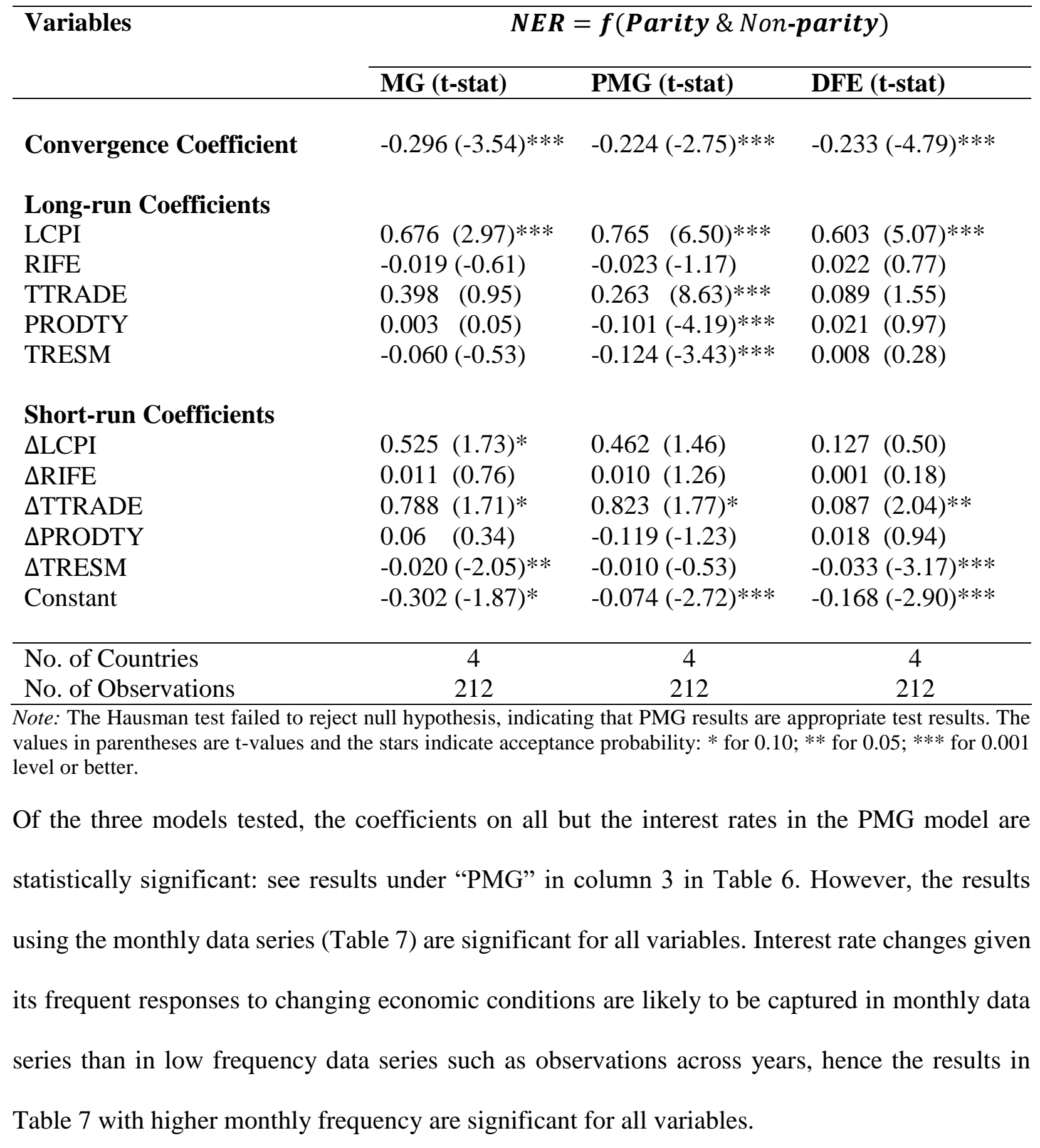


Table 7: Results from Mean Group, Pooled Mean Group and Dynamic Fixed Effect (Monthly Series)

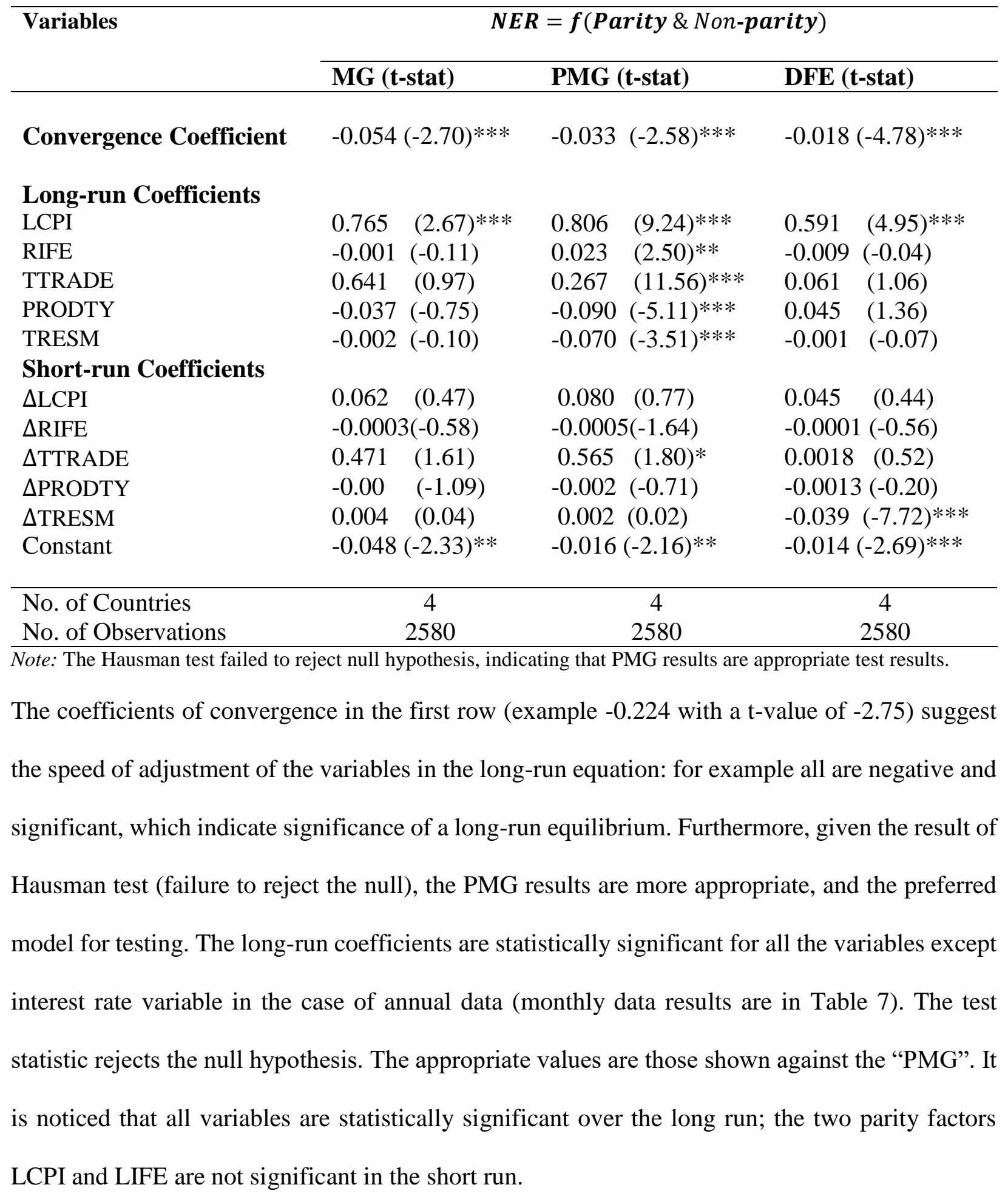


These results constitute robustness testing of the findings discussed in earlier sub-sections. There is a significant support for both parity and non-parity factor effects on exchange rates of the four major countries with free-floating currency regime.

Further, productivity and total reserve, which are non-parity factors, are only relevant for long run exchange rate determination. This makes sense in that these are factors that change in the long run only while productivity is also a long-run variable. The third non-parity factor, total trade, which can change rapidly in the short run in response to changing competitiveness, is shown to be significant in the short run with a t-value of 1.80 .

\section{Conclusion}

This paper considered new way to re-state the often-tested parity theorems using monetary economics variables to verify if methodology as applied in this research makes a difference to the existing consensus that there is no unanimous support for price parity theorems. The literature also suggests that perhaps a more appropriate econometric approach is needed to reveal the underlying behavior to solve this "puzzle". Our maintained hypotheses are that the relative prices and relative interest rates are significant parity factors, and must therefore be statistically upheld via a different approach. The US, the UK, Japanese and Canadian data are used since data are available for these economies readily over a long horizon. The methods used are panel cointegration and the robust DOLS, followed by mean group, pooled mean group and dynamic fixed effect modelling.

The results reveal that both the PPP and IFE theorems are supported, which is a new finding for four key countries practising free-floating monetary policy. The parity factors hold very well in this effort to test them. If the correct lags and leads are specified in a dynamic model as done, then a simple test of just the parity factors provided support for the theorems. The speed of adjustment 
suggests a four-year time length to long run equilibrium for the exchange rate to adjust to full equilibrium. This latter evidence is consistent with the time-to-equilibrium estimated in two key papers in the literature. Application of the research approach in this paper to further free-floating economies may reveal findings to generalize our findings reported in this paper.

There has been discussion about a tax effect on exchange rate tests involving interest rates: this is termed the Darby Hypothesis (Darby, 1975; Feldstein, 1976). ${ }^{5}$ Lack of support for Darby Hypothesis is another puzzle. It is possible there is a tax effect, which we have not attempted to model in this research. If such an effect existed, our estimated coefficients on interest rate are likely to be larger than reported here because the after-tax coefficient would be the reported coefficients divided by (1-tax rate). Not considering the tax effect is a limitation of this study although our reason for excluding tax effect is based on our belief that tax-effect model needs a separate research, which we suggest is worth as a follow up of this study.

\footnotetext{
${ }^{5}$ An anonymous reviewer commented that the paper has not considered a tax effect from interest rate, which yield incomes subjected to taxes. We are grateful for this comment. Perhaps extending our models in a newer direction may help to extend this current research further into tax effect study as a separate research.
} 


\section{References}

Bahmani-Oskooee, M., Kutan, A. M., \& Zhou, S. (2009). Towards solving the PPP puzzle: evidence from 113 countries. Applied Economics, 41(24): 3057-3066.

Breusch, T. S. (1978). Testing for autocorrelation in dynamic linear models. Australian Economic Papers, 17(31): 334-355.

Breusch, T. S., \& Pagan, A. R. (1979). A simple test for heteroscedasticity and random coefficient variation. Econometrica: Journal of the Econometric Society 1287-1294.

Calvo, G. A., Izquierdo, A., \& Talvi, E. (2003). Sudden stops, the real exchange rate, and fiscal sustainability: Argentina's lessons: National Bureau of Economic Research.

Camarero, M., \& Tamarit, C. (1996). Cointegration and the PPP and the UIP hypotheses: An application to the Spanish integration in the EC. Open Economies Review, 7(1): 61-76.

Canarella, G., Miller, S. M., \& Pollard, S. K. (2014). Purchasing Power Parity Between the UK and Germany: The Euro Era. Open Economies Review, 25(4): 677-699.

Cassel, G. (1918). Abnormal deviations in international exchanges. The Economic Journal, 28(112): 413-415.

Cumby, R. E., \& Obstfeld, M. (1981). A Note on Exchange-Rate Expectations and Nominal Interest Differentials: A Test of the Fisher Hypothesis. The Journal of Finance, 36(3): 697703.

Darby, M. R. (1975). The financial and tax effects of monetary policy on interest rates. Economic Inquiry, 13(2): 266-276.

Dickey, D. A., \& Fuller, W. A. (1981). Likelihood ratio statistics for autoregressive time series with a unit root. Econometrica: Journal of the Econometric Society 1057-1072.

Dimitriou, D., \& Simos, T. (2013). Testing purchasing power parity for Japan and the US: A structural-break approach. Japan and the World Economy, 28(0): 53-59.

Dornbusch, R. (1976). Expectations and Exchange Rate Dynamics. Journal of Political Economy, 84(6): 1161-1176.

Edison, H. J. (1987). Purchasing power parity in the long run: A test of the dollar/pound exchange rate (1890-1978). Journal of Money, Credit and Banking, 19(3): 376-387.

Edison, H. J., \& Melick, W. R. (1999). Alternative approaches to real exchange rates and real interest rates: three up and three down. International Journal of Finance \& Economics, 4(2): 93-111.

Edison, H. J., \& Pauls, B. D. (1993). A re-assessment of the relationship between real exchange rates and real interest rates: 1974-1990. Journal of Monetary Economics, 31(2): 165-187.

Fama, E., 1984. Forward and spot exchange rates. Journal of Monetary Economics 14, 319-338.

Feldstein, M. (1976). On the theory of tax reform. Journal of Public Economics, 6(1): 77-104.

Fisher, I. (1930) The theory of interest. New York, Macmillan. 
Frankel, J. A., \& Rose, A. K. (1996). Currency crashes in emerging markets: An empirical treatment. Journal of International Economics, 41(3): 351-366.

Frenkel, J. A. (1976). A monetary approach to the exchange rate: doctrinal aspects and empirical evidence. the scandinavian Journal of economics 200-224.

Godfrey, L. G. (1978). Testing against general autoregressive and moving average error models when the regressors include lagged dependent variables. Econometrica: Journal of the Econometric Society 1293-1301.

Gregory, A. W., \& Hansen, B. E. (1996). Residual-based tests for cointegration in models with regime shifts. Journal of Econometrics, 70(1): 99-126.

Hall, S. G., Hondroyiannis, G., Kenjegaliev, A., Swamy, P., \& Tavlas, G. S. (2013). Is the relationship between prices and exchange rates homogeneous? Journal of International Money and Finance, 37 411-438.

Hatemi-J, A. (2008). Tests for cointegration with two unknown regime shifts with an application to financial market integration. Empirical Economics, 35(3): 497-505.

Hill, C. H. (Ed.). (2004), International business: Competing in the global marketplace (5 ed.). McGraw-Hill College

Ho, C. S. F., \& Ariff, M. (2012). Time to equilibrium in exchange rates: G-10 and Eastern European economies. Global Finance Journal, 23(2): 94-107.

Holmes, M. J. (2008). Real exchange rate stationarity in Latin America and relative purchasing power parity: A regime switching approach. Open Economies Review, 19(2): 261-275.

Im, K. S., Pesaran, M. H., \& Shin, Y. (1995). Testing for unit roots in heterogeneous panels Working Paper: Cambridge University.

Johansen, S. r., \& Juselius, K. (1992). Testing structural hypotheses in a multivariate cointegration analysis of the PPP and the UIP for UK. Journal of Econometrics, 53(1-3): 211-244.

Kao, C., \& Chiang, M.-H. (2001). On the estimation and inference of a cointegrated regression in panel data. Advances in econometrics, 15 179-222.

Kim, Y. (2000). Causes of capital flows in developing countries. Journal of International Money and Finance, 19(2): 235-253.

Levin, A. T., \& Lin, C.-F. (1992). Unit root tests in panel data: asymptotic and finite-sample properties: University of California at San Diego, Economics Working Paper Series.

Lothian, J. R., \& Taylor, M. P. (1996). Real exchange rate behavior: the recent float from the perspective of the past two centuries. Journal of Political Economy 488-509.

Manzur, M., \& Ariff, M. (1995). Purchasing power parity: new methods and extensions. Applied Financial Economics, 5(1): 19-26.

Marini, G., \& Piersanti, G. (2003). Fiscal deficits and currency crises. CEIS Tor Vergata-Research Paper Series(15).

Mark, N. C. (1985). Some evidence on the international inequality of real interest rates. Journal of International Money and Finance, 4(2): 189-208. 
Mark, N. C., \& Sul, D. (2003). Cointegration Vector Estimation by Panel DOLS and Long-run Money Demand*. Oxford Bulletin of Economics and Statistics, 65(5): 655-680.

Martínez, J. (1999). Mexico's balance of payments and exchange rates: a cointegration analysis. The North American Journal of Economics and Finance, 10(2): 401-421.

Meese, R., \& Rogoff, K. (1988). Was It Real? The Exchange Rate-Interest Differential Relation over the Modern Floating-Rate Period. The Journal of Finance, 43(4): 933-948.

Mishkin, F. S. (1984). Are Real Interest Rates Equal Across Countries? An Empirical Investigation of International Parity Conditions. The Journal of Finance, 39(5): 1345-1357.

Mollick, A. V. (1999). The real exchange rate in Brazil Mean reversion or random walk in the long run? International Review of Economics \& Finance, 8(1): 115-126.

Pedroni, P. (1999). Critical Values for Cointegration Tests in Heterogeneous Panels with Multiple Regressors. Oxford Bulletin of Economics and Statistics, 61(S1): 653-670.

Pedroni, P. (2004). Panel Cointegration: Asymptotic and Finite Sample Properties of Pooled Time Series Tests with an Application to the PPP Hypothesis. Econometric Theory, 20(3): 597625.

Pesaran, M. H., Shin, Y., \& Smith, R. P. (1999). Pooled mean group estimation of dynamic heterogeneous panels. Journal of the American statistical Association, 94(446): 621-634.

Pesaran, M. H., \& Smith, R. (1995). Estimating long-run relationships from dynamic heterogeneous panels. Journal of Econometrics, 68(1): 79-113.

Phillips, P. C., \& Perron, P. (1988). Testing for a unit root in time series regression. Biometrika, 75(2): 335-346.

Ramsey, J. B. (1969). Tests for specification errors in classical linear least-squares regression analysis. Journal of the Royal Statistical Society. Series B (Methodological) 350-371.

Rivera-Batiz, F. L., \& Rivera-Batiz, L. A. (2001). International financial liberalization, capital flows, and exchange rate regimes: an introduction. Review of International Economics, 9(4): 573-584.

Rogoff, K. (1996). The purchasing power parity puzzle. Journal of Economic literature, 34(2): 647-668.

Shively, P. A. (2001). A test of long-run purchasing power parity. Economics Letters, 73(2): 201205.

Stock, J. H., \& Watson, M. W. (1993). A simple estimator of cointegrating vectors in higher order integrated systems. Econometrica: Journal of the Econometric Society 783-820.

Throop, A. W. (1993). A generalized uncovered interest parity model of exchange rates Economic Review (Vol. 2, pp. 3-16). Federal Reserve Bank of San Francisco. 